\title{
Pancreatic islet cell survival following islet isolation: the role of cellular interactions in the pancreas
}

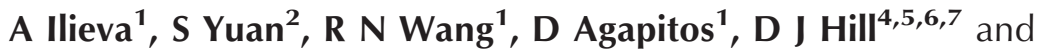 \\ L Rosenberg ${ }^{1,2}$
}

${ }^{1}$ Department of Surgery, McGill University, Montreal, Quebec, Canada

${ }^{2}$ Department of Pathology, McGill University, Montreal, Quebec, Canada

${ }^{3}$ Montreal General Hospital Research Institute, Montreal, Quebec, Canada

${ }^{4}$ Lawson Research Institute, University of Western Ontario, London, Ontario, Canada

${ }^{5}$ Department of Medicine, University of Western Ontario, London, Ontario, Canada

${ }^{6}$ Department of Physiology, University of Western Ontario, London, Ontario, Canada

${ }^{7}$ Department of Paediatrics, University of Western Ontario, London, Ontario, Canada

(Requests for offprints should be addressed to L Rosenberg, Montreal General Hospital, 1650 Cedar Avenue, L9-424, Montreal, Quebec, Canada H3G 1A4)

\begin{abstract}
The purpose of this study was to characterize the trophic effect of pancreatic duct cells on the islets of Langerhans. Ductal epithelium and islets were isolated from hamster pancreata. In addition, duct-conditioned medium (DCM) was prepared from primary duct cultures that had been passaged twice to remove other cellular elements. Three experimental groups were then established: Group 1, 100 islets alone; Group 2, 100 islets+80 duct fragments; and Group 3, 100 islets in 25\% DCM. All tissues were embedded in rat tail collagen for up to 12 days and the influence of pancreatic ductal epithelium on islet cell survival was examined. By day $12,20 \cdot 6 \pm 3 \cdot 0 \%$ (s.E.M.) of the islets cultured alone developed central necrosis, compared with $6.7 \pm 2.0 \%$ of the islets co-cultured with ducts and $5 \cdot 6 \pm 1 \cdot 5 \%$ of the islets cultured in DCM $(P<0 \cdot 05)$. The presence of apoptotic cell death was determined by a TdT-mediated dUTP-biotin nick end labelling (TUNEL) assay and by a specific cell death ELISA. DNA
\end{abstract}

fragmentation in islets cultured alone was significantly increased compared with islets cultured either in the presence of duct epithelium or in DCM $(P<0 \cdot 05)$. More than $80 \%$ of TUNEL-positive cells were situated in the inner $80 \%$ of the islet area, suggesting that most were $\beta$-cells. DCM was analysed for known growth factors. The presence of a large amount of IGF-II $(34 \mathrm{ng} / \mathrm{ml})$ and a much smaller quantity of nerve growth factor $(4 \mathrm{ng} / \mathrm{ml})$ was identified. When the apoptosis studies were repeated to compare islets alone, islets+DCM and islets+IGF-II, the cell death ELISA indicated that IGF-II produced the same beneficial result as DCM when compared with islets cultured alone.

We conclude that pancreatic ductal epithelium promotes islet cell survival. This effect appears to be mediated in a paracrine manner by the release of IGF-II from cells in the ductal epithelium.

Journal of Endocrinology (1999) 161, 357-364

\section{Introduction}

After more than 20 years of concerted research and over 300 attempts at human islet transplantation, the achievement of insulin independence remains elusive (Socci et al. 1991, Warnock et al. 1992, Hering et al. 1995).

It is perhaps significant that the major emphasis on islet transplantation has been the enhancement of the purity of the islet preparation to promote engraftment and reduce immunogenicity (Scharp \& Lacy 1989). The emphasis on purity presupposes that islet survival is independent of other cellular and matrix elements of the pancreas, yet this hypothesis has never been tested. Therefore the loss of trophic support as a cause of islet graft failure, because of the absence of a suitable microenvironment, needs to be explored.

It is known, for example, that a connection between pancreatic duct epithelial cells and islets is established at an early stage of pancreatic morphogenesis (Githens 1993). Endocrine cells develop by a budding process from embryonic duct-like cells and this process leads to the formation of primitive islets in the mesenchyme adjacent to the ducts (Githens 1993). The final stage of phenotypic expression and cellular differentiation may in fact be controlled by the proximity of cells to a local stimulus originating in the pancreas itself (Fell \& Grobstein 1968, Crick 1970). In this regard, the role of cell-cell and cell-matrix interactions in cell development and 
differentiation in the pancreas appears to be of particular importance (Pictet et al. 1975, Spooner et al. 1977, Montesano et al. 1983, Dudek et al. 1991). Possible mechanisms of action include secretion of an inducing factor, information exchange through cell-cell contact, and production of extracellular matrix that contains a critical trophic factor.

We have demonstrated that the cellular interrelationships which exist in the pancreas during embryological development are subsequently conserved, and that islet neogenesis can be induced in the adult pancreas (Rosenberg et al. 1990, 1992). Moreover, we have already reported that duct epithelial cells appear to secrete a soluble factor(s) that exert(s) a proliferative effect on fully mature islet cells (Metrakos et al. 1993). In the present study, we extend our original observations to describe the influence of pancreatic duct epithelium on islet cell survival in vitro, and characterize for the first time the specific growth factors involved in an islet-duct paracrine interaction.

\section{Materials and Methods}

\section{Animals}

Experiments were carried out with 8-week-old female Syrian golden hamsters, 85 g body weight (Charles River, St Jean, QC, Canada), and Canadian Council for Animal Care guidelines for the care and use of experimental animals were strictly followed throughout the study.

\section{Duct isolation}

The hamster pancreatic duct isolation was performed with collagenase XI solution (1 mg/ml) (Sigma Chemical Co., St Louis, MO, USA) as previously described (Yuan et al. 1995). Digestion was carried out in a stationary waterbath at $37^{\circ} \mathrm{C}$ for $30 \mathrm{~min}$, followed by a $10 \mathrm{~s}$ dispersion by vortexing. After washing, the digest was filtered through a $94 \mu \mathrm{m}$ steel mesh filter (Bellco Glass, Vineland, NJ, USA). The retained fragments were harvested by rinsing the inverted filter. The tissues were embedded into neutralized rat tail collagen according to Richards et al. (1983) and cultured in $2 \mathrm{ml}$ Dulbecco's modified Eagle's medium/F12 (DMEM/F12) (Sigma) supplemented with 10\% NuSerum (Collaborative Research Inc., Bedford, MA, USA), insulin $(1 \mu \mathrm{g} / \mathrm{ml}$, Eli Lilly, Toronto, ON, Canada), dexamethasone $(1 \mathrm{~g} / \mathrm{l})$, soybean trypsin inhibitor $(0.1 \mathrm{mg} / \mathrm{ml}$, Gibco, Burlington, ON, Canada), cholera toxin (CT) $(100 \mathrm{ng} / \mathrm{ml}$, Sigma), epidermal growth factor (EGF) $(10 \mathrm{ng} / \mathrm{ml}$, Sigma), penicillin $(100 \mathrm{U} / \mathrm{ml}$, Gibco) and streptomycin $(100 \mu \mathrm{g} / \mathrm{ml}$, Gibco). After 10-12 days of culture, the collagen gel was dissolved by $0 \cdot 25 \mathrm{mg} / \mathrm{ml}$ collagenase. Primary duct epithelial cysts were harvested, washed and re-embedded as before. This process was repeated twice to produce a culture of intralobular ductules by the 3 rd week. The final tertiary duct culture was completely devoid of islets, acini and fibroblasts.

\section{Duct-conditioned medium (DCM)}

DCM was prepared from purified tertiary ducts incubated at $37^{\circ} \mathrm{C}$ for 3 days in DMEM/F12 without NuSerum, $\mathrm{CT}$, EGF or insulin. The conditioned medium was collected and stored at $-80{ }^{\circ} \mathrm{C}$.

\section{Islet isolation}

Islets were isolated from hamster pancreata according to a method previously established in our laboratory (Gray \& Morris 1987, Metrakos et al. 1992, 1993). In brief, $4 \mathrm{ml}$ collagenase P (Boehringer Mannheim, Laval, QC, Canada) solution at $0.7 \mathrm{mg} / \mathrm{ml}$ were slowly introduced into the common bile duct after occlusion of the distal end just proximal to the duodenum. The distended pancreas was excised and the digestion was performed in a waterbath at $37^{\circ} \mathrm{C}$ for $30 \mathrm{~min}$. Islet purification was achieved using a two-step, discontinuous density gradient of BSA (Sigma). Islets were collected from the interface between the 1.000 and $1.081 \mathrm{~g} / \mathrm{ml}$ layer. To ensure $100 \%$ purity of the preparation, islets were hand-picked and counted under an inverted microscope (Nikon TMS, Japan). The islets were recovered overnight in RPMI 1640 (Gibco) supplemented with $4 \% \mathrm{NuSerum}$, penicillin $(100 \mathrm{U} / \mathrm{ml})$ and streptomycin $(100 \mu \mathrm{g} / \mathrm{ml})$.

\section{Analysis of islet-duct interaction}

Ducts and islets were harvested and embedded in rat tail collagen according to the following experimental design: Group 1 (islets alone - control), 100 islets per culture flask; Group 2 (islets plus ducts), 100 islets plus 80 ducts per flask; and Group 3 (islets plus 25\% DCM), 100 islets per flask. Eight flasks were established per group in order to ensure sufficient tissue for all proposed studies.

Each group was initially incubated for 3 days in a baseline medium of DMEM/F12 supplemented with $10 \%$ NuSerum. After day 3, the medium was changed to serum-free DMEM/F12 (Groups 1 and 2) or to DMEM/F12 plus 25\% DCM (Group 3). The medium was changed every other day, and islets were retrieved from the collagen for study on days 1, 3, 6 and 12. A 12 day period of culture was chosen because pilot studies had indicated that there were no new or additional changes in morphology after this time.

\section{Assessment of islet morphology}

In vivo microscopy $\mathrm{To}$ calculate the number of islets with central necrosis in each experimental group, inverted 
light microscopy was used to monitor morphological changes in the islets throughout the incubation period. The same tissue fields were photographed and counted at $1,3,6,8$ and 12 days. Necrosis at the centre of an islet was characterized by a zone of very dark cells that was sharply demarcated from the surrounding viable islet tissue. The number of islets with central necrosis was counted and expressed as a percentage of the total. Islet size $(\mu \mathrm{m})$ and the size of the area of necrosis were determined using a calibrated graticule mounted in the eyepiece of the microscope.

Histology Culture dishes were sampled on days 1, 6 and 12 . The tissue was fixed in $4 \%$ paraformaldehyde and embedded in paraffin. Serial sections $(5 \mu \mathrm{m}$ thick and $50 \mu \mathrm{m}$ apart) were cut from each block, stained with haematoxylin and eosin (H\&E) or toluidine blue and then processed further for routine light microscopy.

Immunocytochemistry Consecutive $5 \mu \mathrm{m}$ sections cut from the tissue block were immunostained for islet cell hormones (anti-human insulin antibody or rabbit polyclonal anti-glucagon or anti-somatostatin antibodies at a dilution of 1:100, Dako Corp., CA, USA), using the streptavidin-biotin complex method as described previously (Wang et al. 1997). The islet hormones were detected using naphtol-AS-MX-phosphate/fast red TR salt as chromagen to obtain a red reaction product. Negative controls were tissues processed with nonimmune serum substituting for the primary antibodies. To identify the presence of apoptotic cells, the tissues were co-processed for the TdT-mediated dUTP-biotin nick end labelling (TUNEL) reaction (see below).

\section{Detection of apoptotic cell death}

After a 12 day incubation period, the media were removed and $3 \mathrm{ml}$ collagenase XI $(0 \cdot 25 \mathrm{mg} / \mathrm{ml})$ were added to each flask for $40 \mathrm{~min}$. The islets were hand-picked and washed three times in Hank's buffered salt solution (Gibco). The presence of DNA fragmentation, a characteristic feature of apoptosis, was determined using a cell death detection ELISA (Boehringer Mannheim). The results were expressed as absorbance at $405 \mathrm{~nm}$ and corrected for total DNA content. DNA was measured by fluorometry using disbenzimidazole (Hoechst 33258, Sigma) as described (Labarca \& Pagen 1987).

To identify which cells in the islet were undergoing apoptosis, a TUNEL assay was employed. Islets were fixed in $4 \%$ paraformaldehyde, embedded in paraffin and $5 \mu \mathrm{m}$ sections cut and pretreated with $0.1 \%$ trypsin buffer at $37^{\circ}$ for $5 \mathrm{~min}$. The In Situ Cell Death Detection Kit (Boehringer Mannheim) was used for the labelling of apoptotic cells and the sections were developed with diaminobenzidine (Sigma). To reduce non-specific labelling the anti-fluorescent antibody conjugated with horse-radish peroxidase was diluted 1:5 in TBS buffer. Approximately 800 cells from ten islets were counted in each group and an apoptotic index (per cent of labelled cells) was calculated.

\section{Analysis of culture medium for growth factors}

Samples of DCM were subjected to acid gel chromatography on Sephadex G50 to separate insulin-like growth factor (IGF)-binding proteins prior to performing specific RIAs for IGF-I and IGF-II. These assays were carried out as described by Hill (1990).

Assay for nerve growth factor (NGF) was performed using an ELISA kit from Boehringer Mannheim. Mouse NGF was used as standard. The antibody specifically reacts with the $\beta$-subunit of NGF, and cross reacts with hamster tissues.

\section{Analysis of the effect of IGF-II}

The islets were embedded in rat tail collagen and cultured in DMEM/F12 supplemented with 10\% NuSerum. After 3 days in culture, three experimental groups were designed for this study: Group 1 (control), islets cultured in DMEM/F12; Group 2, islets cultured in DMEM/F12+ 25\% DCM; and Group 3, islets cultured in DMEM/F12+ $34 \mathrm{ng} / \mathrm{ml}$ IGF-II. The islets were retrieved from the collagen following 9 days in culture with these media.

\section{Statistical analysis}

The results obtained for all culture flasks within a group were pooled and expressed as mean \pm s.E.M. The differences between the three experimental groups with respect to the presence of central necrosis, cytoplasmic DNA fragmentation and apoptotic index were analysed by unpaired Student's $t$-test. The relationship between islet size and the presence or absence of central necrosis, and the relationship between islet size and the size of the area of necrosis, were determined by Chi-square analysis. Except for the IGF-II apoptosis study, all experiments were performed twice and the results were averaged, with $P$ values less than $0 \cdot 05$ considered significant.

\section{Results}

\section{Characteristics of islets and ducts following isolation}

The average number of islets isolated was $475 \pm 108$ per pancreas. Immediately after isolation, islet purity, as determined by dithazone staining, ranged from 80 to $95 \%$, but this reached nearly $100 \%$ on the second day following the final transfer of islets onto the culture dishes. Islet diameter ranged from 50 to $300 \mu \mathrm{m}$, with the majority measuring 100-200 $\mu \mathrm{m}$. Under the inverted microscope, freshly isolated islets had a smooth appearance with slightly 

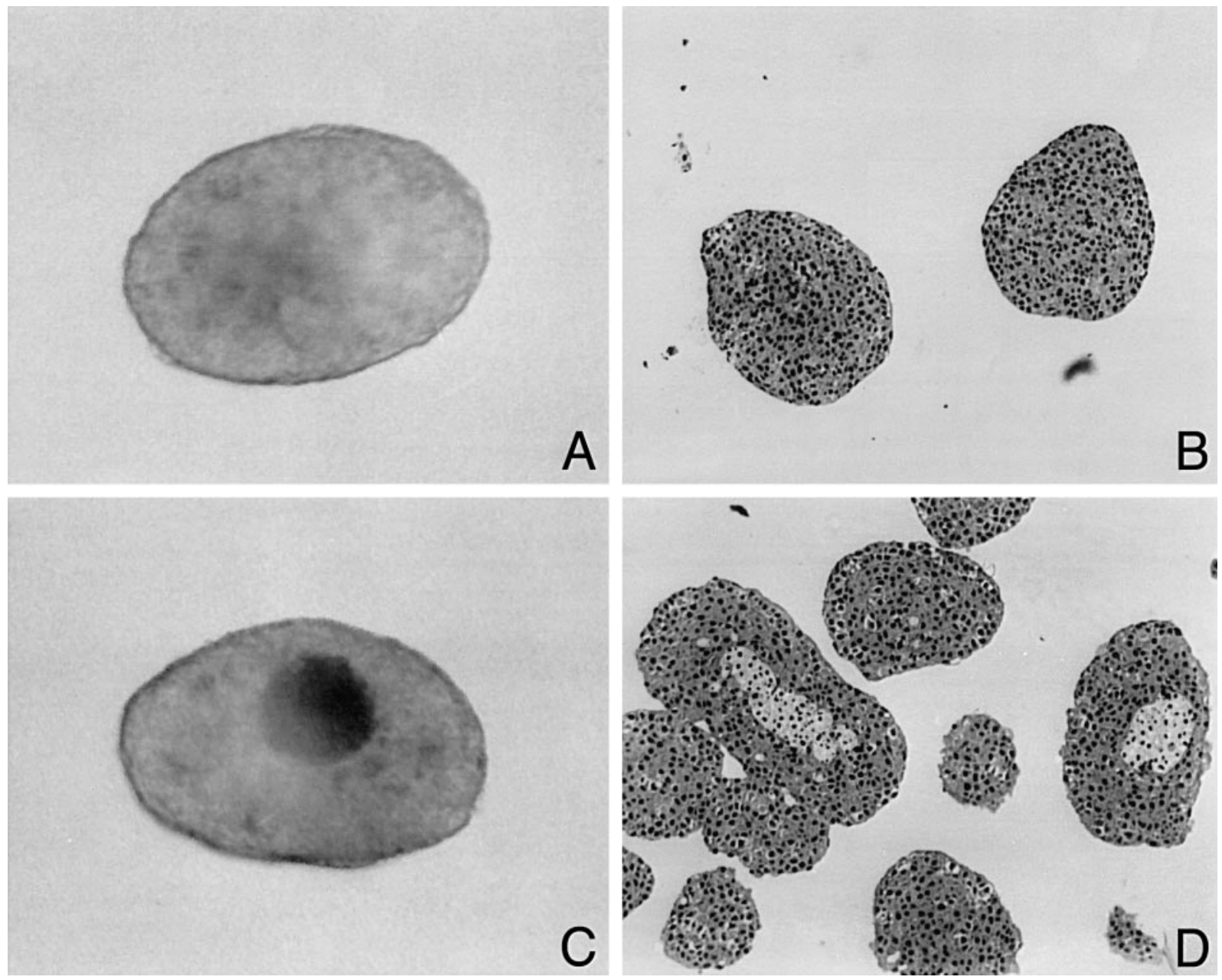

Figure 1 (A) Time-lapsed photograph ( $\times 100$ ) of an islet of Langerhans, embedded in collagen, on day 1 . Note the absence of central necrosis. (B) Light micrograph of islets $(\mathrm{H \& E} ; \times 156)$ cultured for 1 day in the absence of pancreatic ductal epithelium showing normal islet morphology. (C) Time-lapsed photograph $(\times 100)$ of the same islet shown in $(A)$, day 6 . Note the presence of a dark central area of cell necrosis. (D) Light micrograph $(\mathrm{H \& E} ; \times 156)$ of islets cultured for 6 days in the absence of pancreatic ductal epithelium. Some islets show development of central necrosis, while others appear normal.

irregular borders. After overnight incubation, the islets recovered a more regular spherical shape with welldefined smooth borders.

At the start of the study, the mean islet diameter was similar in each of the three treatment groups - islets alone $(161 \pm 34 \mu \mathrm{m})$ vs islets+ducts $(164 \pm 61 \mu \mathrm{m})$ vs islets+DCM $(155 \pm 51 \mu \mathrm{m})$.

More than 2000 duct epithelial cysts were isolated per gram of pancreatic tissue. Following two passages, cultures of pure duct epithelial cysts were obtained, with the lining wall composed of a single layer of cubical or flattened epithelium.

\section{Analysis of morphological changes}

After 1 day, the islets in each group had a normal morphological appearance. The islet cells were compact, regularly shaped, with well-defined nuclei and a grainy appearance of the cytoplasm, and there was no evidence of central necrosis (Fig. 1A and B).

After day 3, a central area of very dark tissue with borders sharply demarcating the surrounding islet cells became visible. By routine histology, this central area was shown to be composed of necrotic cells in the islet core. By day 6 , extensive areas of necrotic cells in the central islet region were apparent (Fig. 1C and D).

Islets cultured alone had a significant increase in central necrosis $(P<0 \cdot 001)$ at all time points when compared with islets in the other two groups (Fig. 2). By day 12, $20.6 \pm 3 \%$ of the islets cultured alone were necrotic, compared with $6 \cdot 7 \pm 2 \%$ of the islets co-cultured with ducts and $5 \cdot 6 \pm 1 \cdot 5 \%$ of the islets cultured in DCM. There was no difference between islets in the duct co-culture and DCM groups. 


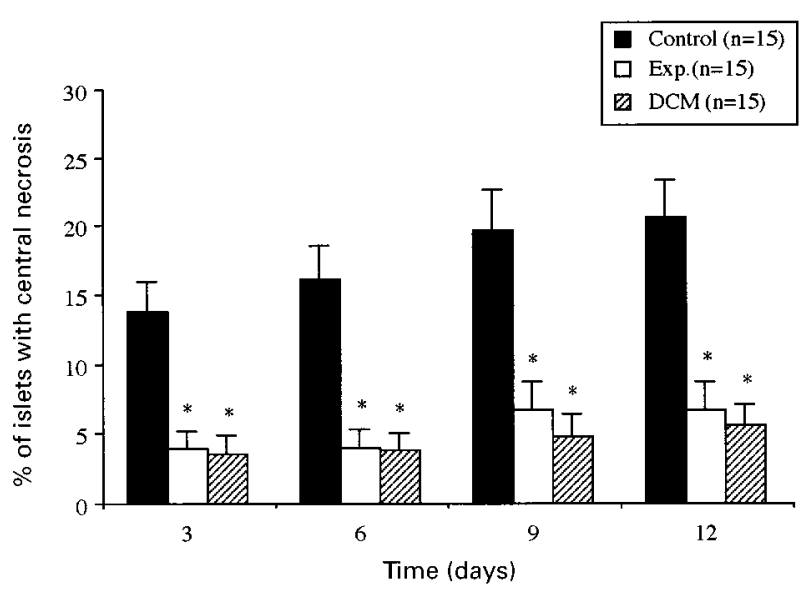

Figure 2 Effect of ductal epithelium and DCM on the development of islet necrosis. Data are means \pm S.E.M. ${ }^{*} P<0 \cdot 001$.

The presence or absence of central necrosis was associated with islet size $(P<0 \cdot 01)$, with the area of necrosis being greatest in islets larger than $150 \mu \mathrm{m}$. Halfway through the study period, there was no significant difference in the mean diameter of islets with central necrosis whether they were cultured alone $(192 \pm 49 \mu \mathrm{m})$, cocultured with ducts $(209 \pm 46 \mu \mathrm{m})$ or cultured with DCM (187 $\pm 42 \mu \mathrm{m})$.

Islets in all groups were normally granulated with insulin at the start of the study. Over the course of the study period, islets in Group 1 slowly lost their insulin immunoreactivity compared with islets in Groups 2 and 3. This was most marked at the end of the study on day 12 (Fig. 3A and B).

\section{Analysis of cell survival}

After 12 days of culture, islets in the duct co-culture and DCM groups showed less evidence of apoptosis compared with islets cultured alone. Using the cell death ELISA, the cytoplasmic nucleosome content of islets cultured alone was increased significantly when compared with islets co-cultured with ducts or islets cultured in medium supplemented with DCM $(2 \cdot 3 \pm 0 \cdot 2$ versus $0 \cdot 9 \pm 0 \cdot 5$ and $1.1 \pm 0.8 ; P<0 \cdot 05$ ). The apoptotic index (per cent TUNEL-positive cells) demonstrated a significant difference $(P<0 \cdot 001)$ between islets cultured alone $(60 \cdot 8 \pm 3 \cdot 9 \%)$ compared with those co-cultured with ducts $(29 \cdot 8 \pm 8 \cdot 3 \%)$ or in DCM-supplemented medium $(38 \cdot 3 \pm 1 \cdot 5 \%)$. Over $80 \%$ of TUNEL-positive cells were in the inner $80 \%$ of the islet, suggesting that these were primarily $\beta$-cells. Double labelling of cells for islet cell hormones confirmed this impression, although as anticipated many TUNEL-positive cells in fact did not show immunoreactivity for any islet cell hormone. By routine histology, the central areas of some islets appeared to also exhibit characteristic features of necrosis, therefore both
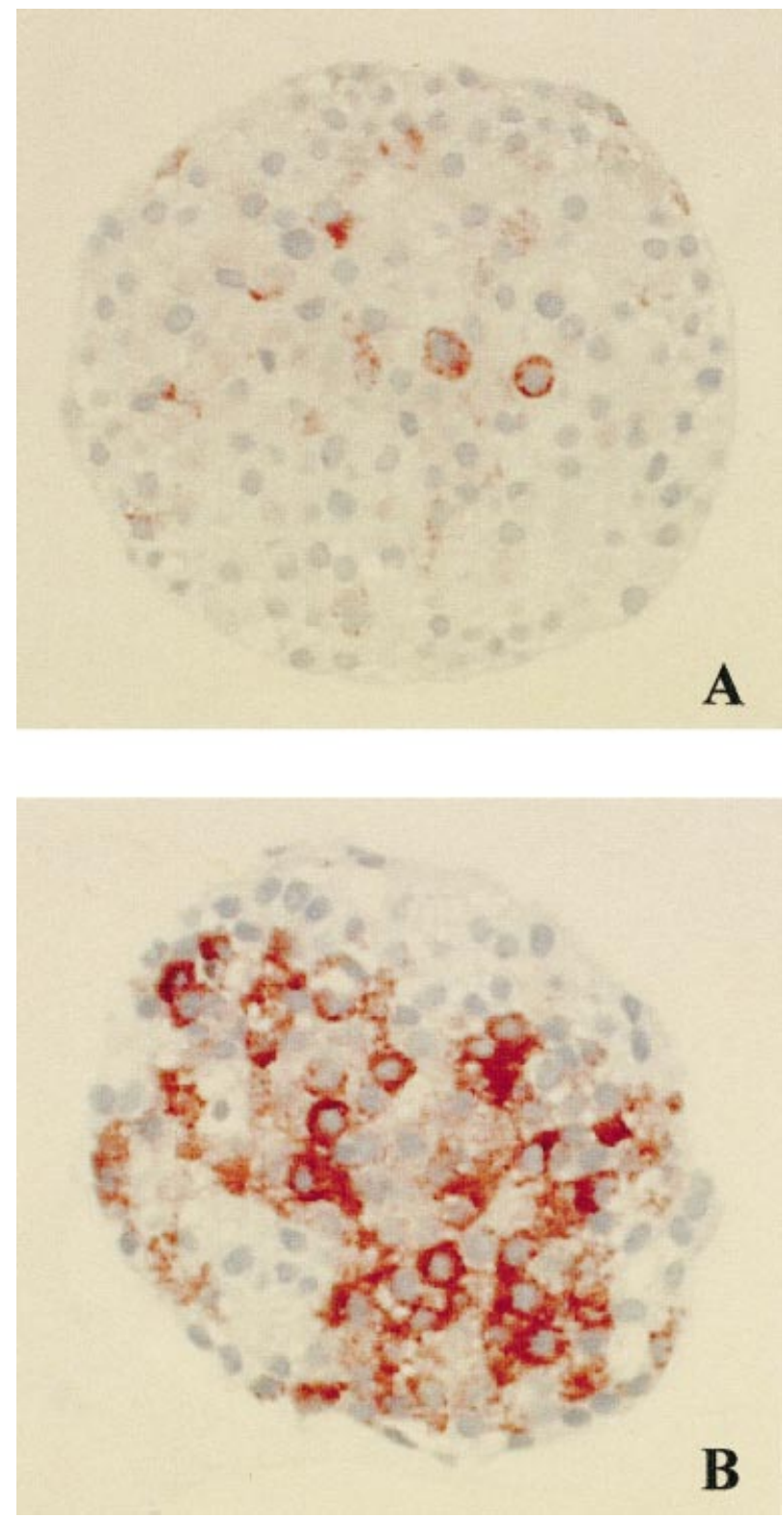

Figure 3 (A) Islet from Group 1 (islets alone) stained for insulin immunoreactivity on day 12 . Note the almost complete loss of insulin. (B) Islet from Group 3 (islets in DCM) stained for insulin immunoreactivity on day 12 . Note the normal pattern of distribution of insulin in the islet. The same finding was observed for islets cultured with ductal epithelium. (Both $\times 400$.)

processes - apoptosis and cell necrosis - were probably responsible for cell loss in the islet core.

\section{Analysis of DCM and the effect of IGF-II}

After completion of this initial series of studies, DCM was analysed for growth factors that might be expected to be 
secretory products of pancreatic ductal epithelium, based on previous literature reports. Our analysis demonstrated the presence of a small amount of NGF $(4 \mathrm{ng} / \mathrm{ml})$ and a much larger amount of IGF-II (34 ng/ml). IGF-I was not identified.

The culture studies were then repeated to compare the outcome by cell death ELISA, for islets cultured alone, to islets+DCM and islets+IGF-II. The results demonstrated that IGF-II could account for the beneficial effect of DCM $(P<0 \cdot 004)$ with respect to limiting apoptosis in cultured islets (islets alone, $4 \cdot 9 \pm 0 \cdot 7$; islets+DCM, $2 \cdot 7 \pm 0 \cdot 4$; islets + IGF, $2 \cdot 5 \pm 1 \cdot 0)$.

\section{Discussion}

We have reported previously that islet-duct co-culture enhances islet cell proliferation in vitro (Metrakos et al. 1993). The present study was designed to further characterize the trophic interrelationships between pancreatic ducts and islets. The hypothesis tested was that islet isolation and purification procedures disrupt cell-cell interrelationships and that this may lead to a loss of trophic support, and hence to a failure of islet cell survival. A duct-islet interaction was chosen because of the embryological origin of islets from ductal epithelium (Rutter 1980) and because this linkage, established early in pancreatic morphogenesis, appears to be subsequently preserved in the post-natal period (Githens 1993).

When maintained under in vitro conditions, islet cells, predominantly in the islet core, were observed to undergo necrotic cell death. This finding is in keeping with a number of previous studies that have documented the occurrence of central necrosis in islets maintained in vitro (Ono et al. 1979, de Graaff et al. 1994, Metrakos et al. 1994). In the present study, however, when islets were co-localized with duct epithelium or with the secretory products of duct cells, the occurrence of central islet necrosis was diminished significantly.

This observation may be explained by two possible mechanisms. First, the presence of central necrosis is generally believed to reflect a diffusion-related phenomenon. This is borne out in part by the demonstration that it is generally the larger islets that are more susceptible to this form of cell death. The adverse effect of islet size would certainly be compounded by the removal of a source of trophic support. Re-establishment of such support, however, could be expected to prevent much of the observed necrosis. This was indeed the case when islets were either co-cultured with ducts or supplemented with DCM. The second is the enhanced $\beta$-cell proliferation that has been reported in the presence of pancreatic duct epithelium (Metrakos et al. 1993). Since the islet core is composed predominantly of $\beta$-cells, the ability of these cells to proliferate when co-cultured with ducts, albeit at a low level, could serve to mitigate, at least in part, the tendency for cell loss due to necrosis.
In contradistinction to cell necrosis, apoptosis represents a form of programmed cell death based on a defined molecular mechanism (Oppenheim 1991, Coles et al. 1993, Finegood et al. 1995), but a variety of environmental factors (Yamada \& Ohyama 1988, Golstein et al. 1991, Itoh et al. 1991, Raff 1992, Levine et al. 1993) have also been shown to induce apoptosis. In addition, we were the first to report the occurrence of islet cell apoptosis following routine islet isolation for human islet transplantation (Paraskevas et al. 1997a).

In the present study, after 12 days of incubation, purified islets sustained a significant increase in apoptotic cell death compared with islets co-cultured with duct cells or those maintained in medium supplemented with DCM. This finding is consistent with the suggestion that islet isolation and purification may trigger apoptosis by removing important trophic factors responsible for the maintenance of islet cell viability (Paraskevas et al. 1997b,c). It remains to be established, however, whether both types of cell death, necrosis and apoptosis, are induced coincidentally by the same set of circumstances, i.e. the withdrawal of trophic factors and the environmental conditions to which the islets are exposed.

These findings suggest that islet isolation and purification, as currently practised, could contribute to an increased rate of islet cell death, and by corollary, to a reduced $\beta$-cell mass for transplantation. A number of clinical and experimental studies lend support to our observations. In patients who underwent total pancreatectomy for the relief of pain due to chronic pancreatitis, followed by an intraportal infusion of a relatively small number of unpurified autologous islets, insulin independence was achieved for up to 6 years (Farney et al. 1991). On the other hand, following autotransplantation of purified islets in a canine model, most grafts were reported to lose function after only 1 year (Kneteman \& Warnock 1990). A similar outcome was obtained even when islets were immunoisolated (Lanza et al. 1992, Soon-Shiong et al. 1992).

The beneficial effect of DCM in reducing both necrotic and apoptotic cell death is interesting in view of the fact that a number of growth factors have been identified in the pancreas (Pictet \& Rutter 1977, Rabinovitch et al. 1982, Romanus et al. 1985, Hill et al. 1987, Polak et al. 1993, Scharfmann et al. 1993, Wang et al. 1993). Growth factors act in a paracrine manner (Goustin et al. 1986, Underwood et al. 1986) to mediate a broad range of cellular responses (Sporn \& Roberts 1987), including extracellular matrix formation, cell proliferation and differentiation. Growth factors may also be inhibitory in almost all situations in which apoptosis is positively stimulated. This suggests that regulation of growth factor levels is not only important in the control of cell proliferation, but also in maintaining viability of cells susceptible to apoptosis (Armato et al. 1986, Raff 1992, Collins et al. 1994). 
The role of these factors in the maintenance of islet cell survival in the pancreas is relatively unexplored, but a role for the IGFs as survival factors has been proposed (Barres et al. 1992). IGFs inhibit apoptosis in mammary carcinoma cells, cerebellar granule neurons, ovarian preovulatory follicles, human erythroid colony-forming cells and haematopoietic cells (Geier et al. 1992, Muta \& Krantz 1993, Chun et al. 1994, Galli et al. 1995). We recently showed that a developmental apoptosis which occurs in the neonatal rat $\beta$-cell population is associated with a loss of local IGF-II expression within the islets (Petrik et al. 1998). A functional link existed since the resistance of isolated islets from newborn rats to cytokine-induced apoptosis was reduced when endogenous IGF-II was immunoneutralized, while older islets, which no longer express IGF-II and are killed by cytokines, could be rescued with exogenous IGF-II. It is, therefore, of considerable importance that we have identified IGF-II as a key trophic element in this in vivo model of islet cell survival. These data suggest that for success in islet transplantation the activity of survival factors may be fundamental to the long-term maintenance of graft function. As such, it is important that in this study we have identified at least one of the necessary factors and its cell of origin.

In summary, we have demonstrated three important outcomes. First, islet cell death from both necrosis and apoptosis occurred during a brief period of culture following islet isolation and purification. Secondly, there was a trophic interaction between pancreatic duct epithelium and islet cells that produced a significant reduction in islet cell death. Thirdly, this interaction was mediated by duct cell secretion of IGF-II into the culture medium. Further studies will be necessary to clarify the precise nature of the interaction and to identify and purify other possible mediators.

\section{Acknowledgements}

This work was supported by grants from the Sam Solomon Fund of the Canadian Diabetes Association, the Medical Research Council of Canada and the Fast Foundation. L R was supported as a Chercheur-Bousier Clinicien (Senior) by the Fond du Recherché du Quebec. The authors gratefully acknowledge Ms Lydia Malynowsky and Ms Adriana Torissi from the Department of Pathology, Montreal General Hospital, for the processing of tissue specimens for histology and immunocytochemistry.

\section{References}

Armato U, Romano F, Andreis PG, Paccagnella L \& Marchesini C 1986 Growth stimulation and apoptosis induced in cultures of neonatal rat liver cells by repeated exposures to epidermal growth factor/urogastrone with or without associated pancreatic hormones. Cell Tissue Research 245 471-480.
Barres BA, Hart IK, Coles HS, Burne JF, Voyvodic JT, Richardson WD \& Raff MC 1992 Cell death and control of cell survival in the oligodendrocyte lineage. Cell 70 31-46.

Chun SY, Billig H, Tilly JL, Furuta I, Tsafriri A \& Hsueh AJW 1994 Gonadotropin suppression of apoptosis in cultured preovulatory follicles: mediatory role of endogenous insulin-like growth factor I. Endocrinology 135 1845-1853.

Coles HSR, Burne JF \& Raff MC 1993 Large-scale normal cell death in the developing rat kidney and its reduction by epidermal growth factor. Development 118 777-784.

Collins MKL, Perkins GR, Rodriguez-Tarduchy G, Nieto MA \& Lopez-Rivas A 1994 Growth factors as survival factors: regulation of apoptosis. Bioessays 16 133-138.

Crick F 1970 Diffusion in embryogenesis. Nature 225 420-422.

Dudek RW, Lawrence IE, Hill RS \& Johnson RC 1991 Induction of islet cytodifferentiation by fetal mesenchyme in adult pancreatic ductal epithelium. Diabetes 40 1041-1048.

Farney AC, Najarian JS, Nakhleh RE, Lloveras G, Field MJ, Gores PF \& Sutherland DE 1991 Autotransplantation of dispersed pancreatic islet tissue combined with total or near-total pancreatectomy for treatment of chronic pancreatitis. Surgery 110 427-437.

Fell PE \& Grobstein C 1968 The influence of extra-epithelial factors on the growth of embryonic mouse pancreatic epithelium. Experimental Cell Research 53 301-304.

Finegood DT, Scaglia L \& Bonner-Weir S 1995 Dynamics of $\beta$-cell mass in the growing rat pancreas: Estimation with a simple mathematic model. Diabetes 44 249-256.

Galli C, Meucci O, Scorziello A, Werge TM, Calissano P \& Schettini G 1995 Apoptosis in cerebellar granule cells is blocked by high $\mathrm{KCl}$, forskolin, and IGF-I through distinct mechanisms of action: the involvement of intracellular calcium and RNA synthesis. Journal of Neuroscience 15 1172-1179.

Geier A, Haimshon M, Beery R \& Lunenfeld B 1992 Insulin-like growth factor-I inhibits cell death induced by cycloheximide in MCF-7 cells - a model system for analyzing control of cell death. In Vitro Cell and Developmental Biology - Animal 28A 725-729.

Githens S 1993 Differentiation and development of the pancreas in animals. In The Pancreas: Biology, Pathobiology, and Disease, edn 2, pp 21-55. Eds VL Go, EP Dimagno, JD Gardner, E Lebenthal, HA Reber \& GA Scheele. New York: Raven Press.

Golstein P, Ojeius DM \& Young D-E 1991 Cell death mechanisms and the immune system. Immunological Reviews $12129-65$.

Goustin AS, Leof EB, Shipley GD \& Moses HL 1986 Growth factors and cancer. Cancer Research 46 1015-1029.

de Graaff MP, Wolters GH \& van Schilfgaarde R 1994 Endothelial cells in pancreatic islets and the effect of culture. Transplantation Proceedings 261171.

Gray DW \& Morris PJ 1987 Development in isolated pancreatic islet transplantation. Transplantation 43 321-331.

Hering BJ, Schultz AO, Geier C, Bretzel RG \& Federlin K 1995 International Islet Transplant Registry Newsletter 52.

Hill DJ 1990 Relative abundance and molecular size of immunoreactive insulin-like growth factors I and II in human fetal tissues. Early Human Development 21 49-58.

Hill DJ, Frazer A, Swenne I, Wirdnam PK \& Milner RD 1987 Somatostatin-C in human fetal pancreas. Diabetes 36 465-471.

Itoh N, Yonehara S, Ishii A, Yonehara M, Mizushima S, Sameshima M, Hase A, Seto Y \& Nagata S 1991 The polypeptide encoded by the cDNA for human cell surface antigen fas can mediate apoptosis. Cell 66 233-243.

Kneteman NM \& Warnock GL 1990 Prolonged function of canine pancreatic fragments autotransplanted to the spleen by venous reflux. Transplantation 49 678-681.

Labarca C \& Pagen K 1987 A simple, rapid and sensitive DNA assay procedure. Analytical Biochemistry 102 44-52.

Lanza RP, Sullivan SJ \& Chick WL 1992 Islet transplantation with immuno-isolation. Diabetes 41 1503-1510. 
Levine B, Huang Q, Isaacs JT, Reed JC, Griffin DE \& Hardwick JM 1993 Conversion of lytic to persistent alphavirus infection by the bcl-2 cellular oncogene. Nature 361 739-742.

Metrakos P, Qi SJ, Agapitos D \& Rosenberg L 1992 Isolation of hamster islets by intraductal collagenase infusion and bovine serum albumin density gradient. Transplantation Proceedings 24 2830-2831.

Metrakos P, Yuan S, Agapitos D \& Rosenberg L 1993 Intercellular communication and maintenance of islet cell mass - implications for islet transplantation. Surgery 114 423-427.

Metrakos P, Yuan S, Qi SJ, Duguid WP \& Rosenberg L 1994 Collagen gel matrix promotes islet cell proliferation. Transplantation Proceedings 26 3349-3350.

Montesano R, Mouron P, Amherdt M \& Orci L 1983 Collagen matrix promotes reorganization of pancreatic endocrine cell monolayers into islet-like organoids. Journal of Cell Biology 97 935-939.

Muta K \& Krantz SB 1993 Apoptosis of human erythroid colonyforming cells is decreased by stem cell factor and insulin-like growth factor I as well as erythropoietin. Journal of Cellular Physiology 156 264-271.

Ono J, Lacy PE, Michael HEB \& Greider MH 1979 Studies of the functional and morphologic status of islets maintained at $24{ }^{\circ} \mathrm{C}$ for four weeks in vitro. American Journal of Pathology 97 489-504.

Oppenheim RW 1991 Cell death during development of the nervous system. Annual Review of Neuroscience 14 453-501.

Paraskevas S, Duguid WP, Maysinger D, Feldman L, Agapitos D \& Rosenberg L 1997a Apoptosis occurs in freshly isolated human islets under standard culture conditions. Transplantation Proceedings 29 750-752.

Paraskevas S, Maysinger D, Lakey JRT, Cavanagh TJ, Wang R \& Rosenberg L $1997 b$ Activation of JNK, p38 and erk in cultured human, canine and porcine islets. Acta Diabetologia 34128.

Paraskevas S, Maysinger D, Lakey JRT, Cavanagh TJ, Wang R \& Rosenberg L 1997c Modulation of jnk and p38 MAP kinase activity by insulin in human, porcine and canine islets. Acta Diabetologia 34 133.

Petrik J, Arany E, McDonald TJ \& Hill DJ 1998 Apoptosis in the pancreatic islet cells of the neonatal rat is associated with a reduced expression of insulin-like growth factor II that may act as a survival factor. Endocrinology 139 2994-3004.

Pictet RL \& Rutter WJ 1977 In Cell Interactions in Differentiation, pp 337. Eds M Karkinen-Jaaskelainen, L Saxen \& L Weiss. London: Academic Press.

Pictet RL, Rall L, de Gasparo M \& Rutter WJ 1975 Regulation of differentiation of endocrine cells during pancreatic development in vivo. In Early Diabetes in Early Life, pp 25. Eds RA CameriniDavalos \& HS Cole. New York: Academic Press.

Polak M, Scharfmann R, Seilheimer B, Eisenbarth G, Dressler D, Verma IM \& Potter H 1993 Nerve growth factor induces neuronlike differentiation of an insulin-secreting pancreatic beta cell line. Proceedings of the National Academy of Sciences of the USA 90 5781-5785.

Rabinovitch A, Quigley C, Russell T, Patel Y \& Mintz DH 1982 Insulin and multiplication stimulating activity (an insulin-like growth factor) stimulate islet $\beta$-cell replication in neonatal rat pancreatic monolayer cultures. Diabetes 31 160-164.

Raff MC 1992 Social controls on cell survival and cell death. Nature 356 397-400.

Richards J, Larson L \& Yang J 1983 Methods for culturing mammary epithelial cells in a rat tail collagen gel matrix. Journal of Tissue Culture Methods 8 31-36.

Romanus JA, Rabinovitch A \& Rechler MM 1985 Neonatal rat islet cell cultures synthesize insulin-like growth factor-I. Diabetes 34 696-792.
Rosenberg L, Clas D \& Duguid WP 1990 Trophic stimulation of the ductal/islet cell axis: a new approach to the treatment of diabetes. Surgery 108 191-197.

Rosenberg L, Duguid WP, Healy M, Clas D \& Vinik AI 1992 Reversal of diabetes by the induction of islet cell neogenesis. Transplantation Proceedings 24 3012-3013.

Rutter WJ 1980 The development of the endocrine and exocrine pancreas. In The Pancreas, pp 30-38. Eds PJ Fitzgerald \& AB Morrison. Baltimore: Williams and Wilkins.

Scharfmann R, Tazi A, Polak M, Kanaka C \& Czernichow P 1993 Expression of functional nerve growth factor receptors in pancreatic beta-cell lines and fetal rat islets in primary culture. Diabetes $\mathbf{4 2}$ 1829-1836.

Scharp DW \& Lacy PE 1989 Islet transplantation: a review of the objective, the concepts, the progress and the failure. In International Handbook of Pancreas Transplantation, pp 455-478. Eds JM Dubernard \& DER Sutherland. Boston: Kluwer Academic Publishers.

Socci G, Falqui L, Davalli AM, Ricordi C, Braghi S, Bertuzzi F, Maffi P, Secchi A, Gavazzi F \& Freschi M 1991 Fresh human islet transplantation to replace pancreatic endocrine function in type I diabetic patients. Acta Diabetologia 28 151-157.

Soon-Shiong P, Feldman E, Nelson R, Komtebedde J, Smidsrod O, Skjak-Braek G, Espevik T, Heintz R \& Lee M 1992 Successful reversal of spontaneous diabetes in dogs by intraperitoneal microencapsulated islets. Transplantation 54 769-774.

Spooner BS, Cohen HI \& Faubion J 1977 Development of the embryonic mammalian pancreas: The relationship between morphogenesis and cyto-differentiation. Developmental Biology 61 119-130.

Sporn MB \& Roberts AB 1987 Peptide growth factors are multifunctional. Nature 332 217-219.

Underwood LE, D’Ercole AJ, Clemmons DR \& Van Wyk JJ 1986 Paracrine functions of somatomedins. Clinical Endocrinology and Metabolism 15 59-77.

Wang RN, Rehfeld JF, Nielsen FC \& Kloppel G 1997 Expression of gastrin and transforming growth factor-alpha during duct to islet cell differentiation in the pancreas of duct-ligated adult rats. Diabetologia 40 887-893.

Wang TC, Bonner-Weir S, Oates PS, Chulak M, Simon B, Merlino GT, Schmidt EV \& Brand SJ 1993 Pancreatic gastrin stimulates islet differentiation of transforming growth factor alpha-induced ductular precursor cells. Journal of Clinical Investigation $\mathbf{9 2}$ 1349-1356.

Warnock GL, Kneteman NM, Ryan E, Rabinobitch A \& Rajotte RV 1992 Long term follow-up after transplantation of insulin-producing pancreatic islets into patients with type I (insulin-dependent) diabetes mellitus. Diabetologia 35 89-95.

Yamada T \& Ohyama H 1988 Radiation-induced interphase death of rat thymocytes is internally programmed (apoptosis). International Journal of Radiation Biology 53 65-75.

Yuan S, Metrakos P, Duguid W \& Rosenberg L 1995 Isolation and culture of intralobular ducts from the hamster pancreas. In Vitro Cell and Developmental Biolog - Animal 31 77-80.

Received 16 September 1998

Revised manuscript received 23 December 1998 Accepted 26 January 1999 